\title{
Gramíneas hospedeiras de Xanthomonas sp., agente causal da falsa estria vermelha da cana-de-açúcar
}

\author{
Elaine Spindola Mantovani ${ }^{1 *}$; Danyelle Cristine Marini² ${ }^{2}$ Éder Antônio Giglioti ${ }^{1,3}$
}

${ }^{1}$ Departamento Biotecnologia Vegetal, Centro de Ciências Agrárias - Universidade Federal de São Carlos, Via Anhanguera Km 174, Caixa Postal 153, Araras, SP, 13607-900; ${ }^{2}$ Instituto de Biociências, Universidade Estadual Paulista Julio Mesquita Filho, A. 24 A, Bela Vista Rio Claro, SP, 13506-900.

${ }^{3}$ Autor para correspondência: Rua Nunes Machado, 279, Edifício Alamandra, apto. 74, Araras, SP, 13.600-020. 〈edergiglioti@ig.com.br> Data de chegada: 30/04/2004. Aceito para publicação em: 08/06/2004.

\begin{abstract}
Mantovani, E. S., Marini, D. C.; Giglioti, E. A. Host range of Xanthomonas sp., causal agent of the false red stripe of sugarcane, among grasses. Summa Phytopathologica, v.32, n. 2, p. 124-130, 2006.

False Red Stripe (FRS), a new disease caused by Xanthomonas sp., is different from any other sugarcane disease already described. It is distributed throughout the main sugarcane areas of the CenterSouth of Brazil but has not been reported in the Northeast and North of Brazil or any other country. The present work determined the host range of the FRS bacterium among grasses crops and weeds, through artificial inoculation by injection and spraying of bacterial suspension. From the 31 different species inoculated with the FRS bacterium, only sorghum, maize and oat expressed symptoms 15 days after inoculation. Sorghum presented coalescent red stripes at the injection point. Under and above the injection point, at the adaxial face of the

$\mathrm{mm})$. The symptoms in sorghum were very similar to those observed in sugarcane; however, no yellowish flex were observed on the stripes. Maize plants presented a generalized discoloration of tissues near the inoculation point and the appearance long chlorotic stripes with 2-3 mm, but no bacterial exudation. Only oat plants expressed symptoms after inoculation by spraying. The FRS bacterium was recovered by re-isolation from the symptomatic leaves of sorghum, maize and oat and its identity was confirmed by serological and RepPCR tests. A survey of sorghum, maize and oat fields should be carried out in order to determine whether or not the FRS bacterium can infect these crops naturally.
\end{abstract} leaves, bacterial exudates were observed on the narrow red stripes (1

Additional keywords: Xanthomonas, sugarcane, host range, artificial inoculation, gramineae (=Poaceae).

\section{RESUMO}

Mantovani, E. S., Marini, D. C.; Giglioti, E. A. Gramíneas hospedeiras de Xanthomonas sp., agente causal da falsa estria vermalha da cana-deaçúcar. Summa Phytopathologica, v.32, n. 2, p.124-130, 2006.

Falsa estria vermelha (FEV), uma nova doença causada por Xanthomonas sp., é diferente diferente de todas as outras doenças já descritas em cana-de-açúcar. Ela está distribuída por toda as principais regiões canavieiras do centro-sul do Brasil, mas ainda não foi detectada no norte e nordeste do Brasil nem em qualquer outro país. $\mathrm{O}$ presente estudo determinou a gama de culturas e plantas daninhas hospedeiras da bactéria dentre espécies pertencentes às gramíneas, através de inoculação por injeção e pulverização de suspensão bacteriana. Além da cana-de-açúcar, entre as 31 diferentes espécies estudadas, apenas sorgo, milho e aveia apresentaram sintomas, 15 dias após a inoculação. Em sorgo, no ponto de inoculação, apareceram estrias avermelhadas coalescentes. As folhas apresentaram típicas estrias vermelhas finas $(1 \mathrm{~mm})$, longas e paralelas às nervuras, com presença de exsudato bacteriano. Até mesmo as inflorescências apresentaram pontuações avermelhadas. Plantas de milho inoculadas com seringa apresentaram sintomas de anasarca e descoloração de tecidos ao redor do ponto de inoculação e estrias cloróticas (2-3 mm) no limbo foliar; porém, sem exsudato de bactéria. Apenas folhas de cevada apresentaram sintomas quando inoculadas por pulverização. As lesões iniciais eram estrias e manchas de cor palha, evoluindo para uma necrose total das folhas, causando a morte das plantas. A partir de folhas sintomáticas de cana-de-açúcar, sorgo, milho e aveia, realizaram-se re-isolamentos, obtendo-se culturas puras de Xanthomonas sp. cuja identidade foi comprovada através de testes sorológicos e por Rep-PCR. Diante desses resultados, surge a necessidade de realização de inspeções e campos de cultivo de sorgo, milho e aveia para verificar a presença da bactéria da FEV e determinar se o patógeno pode infectar essas culturas naturalmente. 
Falsa estria vermelha (FEV) é uma doença da cana-de-açúcar descrita em 1999 que está distribuída por toda a região canavieira do centro-sul do Brasil (2). O nome da doença foi dado em função da dificuldade de se diferenciar seus sintomas daqueles causados por Acidovorax avenae subsp. avenae agente causal de outra doença da cana-de-açúcar chamada Estria Vermelha. Provavelmente, a FEV esteve presente em nossos canaviais sendo confundida com a Estria Vermelha. Os sintomas da FEV são caracterizados pela presença de estrias finas $(1 \mathrm{~mm})$ paralelas à nervura central das folhas de cana-deaçúcar. Frequientemente, as estrias têm uma mistura de cores vermelhas e amarelas, estendendo progressivamente da ponta para o meio e base das folhas. Quando vistas contra a luz solar, as estrias ficam parcialmente translucentes e as mesclas amareladas ficam mais evidentes. Em genótipos altamente suscetíveis, as estrias freqüentemente ficam coalescentes e a cor avermelhada fica predominante. A doença no campo segue um padrão de distribuição generalizado, onde cada planta apresenta pelo menos uma folha com estrias, sendo favorecida por solos de alta fertilidade e ambientes com alta umidade e temperaturas amenas. A FEV é também mais freqüentemente observada nas bordas dos talhões em canaviais com mais de seis meses de idade (4).

Plantas apresentado os sintomas da FEV têm a área foliar capaz de realizar fotossíntese drasticamente afetada o que, conseqüentemente, pode reduzir sua performance quanto à produção de colmos por hectare, principalmente em genótipos altamente suscetíveis. Isso tem sido preocupante, pois alta frequiência, chegando até $23 \%$, de genótipos que são moderadamente ou altamente suscetíveis à FEV tem sido observada nos estágios intermediários dos programas de melhoramento no Brasil $(2,4)$.

Inicialmente, o agente causal da FEV foi identificado como Xanthomonas sp. (3). O padrão de DNA digerido com enzimas de restrição e separados por eletroforese em campo pulsado para a bactéria da FEV foi diferente de todas as outras já isoladas de cana-de-açúcar e outras gramíneas $(1,4)$. Mais recentemente, considerando resultados de um estudo polifásico, incluindo testes de patogenicidade, determinação do perfil metabólico através do Sistema BIOLOG GN, sequenciamento e análise da região $16 \mathrm{~S}$ e 16-23S do DNAr, perfis eletroforéticos gerados por ERIC, REP e BOX-PCR, homologia de DNA-DNA e isolados tipos de 19 espécies de Xanthomonas, a bactéria agente causal da FEV foi classificada como Xanthomonas axonopodis, sendo sugerido um novo patovar para se referir a este patógeno: Xanthomonas axonopodis pv. rubrilineans $(7,15)$.

Desde 1995, quando a doença foi observada no campo pela primeira vez, nenhum sintoma da FEV foi encontrado em outras espécies além da cana-de-açúcar. No entanto, nenhum estudo dirigido para avaliar a possibilidade de existir hospedeiros alternativos para o patógeno da FEV foi conduzido. Neste particular, o presente trabalho teve como objetivo determinar gramíneas hospedeiras de Xanthomonas sp. agente causal da FEV, visando contribuir com futuros estudos epidemiológicos e determinação de medidas de controle da doença.

\section{MATERIALEMÉTODOS}

Espécies de gramíneas e obtenção de plantas. Além da canade-açúcar, foram estudadas 30 diferentes espécies de gramíneas (Tabela 1), incluindo milho, trigo e arroz, e plantas daninhas comumente encontradas infestando campos comerciais de canade-açúcar, como capim colonião, brachiaria e marmelada.

As sementes das diferentes espécies estudadas foram fornecidas pelo Instituto Agronômico de Campinas (IAC) e pelo Laboratório de Microbiologia Agrícola e Molecular (LAMAM) do Centro de Ciências Agrárias da Universidade Federal de São Carlos. As sementes foram inicialmente germinadas em placas de Petri com filtro umedecido, durante três dias em BOD ajustada a $28^{\circ} \mathrm{C}$. Após este período, para cada espécie de gramínea, cinco sementes germinadas foram transplantadas para sacos plásticos contendo $2 \mathrm{Kg}$ de uma mistura de solo:areia:matéria orgânica na proporção 1:1:1. As plantas permaneceram por um período de duas semanas em casa-de-vegetação e depois foram transferidas para um ambiente telado com sombrite, pois observações de campo sugerem que os sintomas da falsa estria vermelha são observados com maior freqüência em ambientes com temperaturas mais amenas e alta umidade (2).

Isolamento do patógeno. A partir de folhas da variedade de cana-de-açúcar RB855113 com sintomas característicos da falsa estria vermelha $(2,3)$, Xanthomonas sp. foi isolada em meio de Wilbrink (Bacto Peptona, $5 \mathrm{~g}$; Sacarose, $10 \mathrm{~g}$; $\mathrm{K}_{2} \mathrm{HPO}_{4} \cdot 3 \mathrm{H}_{2} \mathrm{O}$, $0,5 \mathrm{~g} ; \mathrm{MgSO}_{4} \cdot 7 \mathrm{H}_{2} \mathrm{O}, 0,25 \mathrm{~g} ; \mathrm{Na}_{2} \mathrm{SO}_{3} 0,05 \mathrm{~g} ;$ agar-agar, $15 \mathrm{~g} ; \mathrm{H}_{2} \mathrm{O}$, $1.000 \mathrm{ml}$ ) (17). Inicialmente, segmentos de folhas foram descontaminados superficialmente com algodão e álcool, e então lavados em água destilada. Após essa descontaminação superficial, fragmentos de tecidos infectados foram imersos em álcool 95\% por 1 min, e depois transferidos para solução hipoclorito de sódio 5\%, por $1 \mathrm{~min}$. Em seguida, os fragmentos foram lavados em água destilada por duas vezes. Os fragmentos foram então triturados em $1 \mathrm{ml}$ de água destilada estéril, e o extrato da folha foi diluído em série. Da suspensão $10^{-3}, 100 \mu \mathrm{l}$ foram transferidos para placas de Petri contendo meio Wilbrink e incubados a $28^{\circ} \mathrm{C}$, por $72 \mathrm{~h}$, quando colônias isoladas de Xanthomonas sp. foram observadas. Uma colônia representando um isolado foi então transferida para outra placa de Petri contendo meio de Wilbrink e incubada nas mesmas condições. Ao final, foram obtidos 10 isolados de Xanthomonas sp. (Tabela 2), cuja identidade foi comprovada através de testes sorológicos por aglutinação em lâminas, rep-PCR e Sistema de Microplacas BIOLOG GN $(6,7,14)$. Estes isolados foram idênticos quanto à patogenicidade na variedade RB855113 e ao perfil de bandas obtidas por rep-PCR (5), mesmo sendo isolados de diferentes regiões e anos. Os isolados foram então incubados em meio líquido, a $28^{\circ} \mathrm{C}$, por $24 \mathrm{~h}$, quando então foram adicionados $20 \%$ de glicerol ao meio e a suspensão bacteriana armazenada a $-80^{\circ} \mathrm{C}$.

Inoculação. A partir de cultura de Xantomonas sp. crescida por 72 horas a $28^{\circ} \mathrm{C} \mathrm{em}$ meio Wilbrink, foram preparadas suspensões bacterianas as quais foram ajustadas em espectrofotômetro a uma leitura de $70 \%$ de transmitância no comprimento 
Tabela 1. Espécies e cultivares de gramíneas utilizadas no estudo de gama de hospedeiras de Xanhomonas sp., agente causal da falsa estria vermelha da cana-de-açúcar.

\begin{tabular}{|c|c|c|c|}
\hline Nome vulgar & Nome científico & Variedades & Origem $*$ \\
\hline Cana-de-açúcar & Saccharum spp. L. & RB855113 & CCA/UFSCar \\
\hline Milho & Zea mays & P30, F33 e P30K75 & LAMAN \\
\hline Sorgo & Sorghum bicolor L. Moench & BR700 e BR800 & LAMAN \\
\hline Trigo & Triticum $\mathrm{spp}$ & Fontana, Br40 e IAC 373 & LAMAN \\
\hline Centeio & Secale cereale $\mathrm{L}$. & BR1 & LAMAN \\
\hline Arroz & Oryza sativa $\mathrm{L}$. & Primavera, IAC202, Carisma e Epagri & LAMAN \\
\hline Aveia & Avena sativa $\mathrm{L}$. & AV107, PretaBem29 e URFGS14 & LAMAN \\
\hline Capim-colonião & Panicum maximum Jacq. & H12; H21; HIPO & IAC \\
\hline Milheto & Pennisetum americanum $\mathrm{L}$. & BRS1501 & IAC \\
\hline Triticali & Tritico secali & IAC 02 & LAMAN \\
\hline Trigo & Triticum spp & Fontana; IAC24 e IAC5 & IAC \\
\hline Brachiarão & Brachiara brisanta & BRABR & IAC \\
\hline Brachiaria & Brachiara decumbens & BRADC & IAC \\
\hline Marmelada & Brachiara plantaginea & BRAPL & IAC \\
\hline Capim agulha & Brachiara humidicula & BRAHU & IAC \\
\hline Capim-carrapicho & Cenchrus echinatus & CCHEC & IAC \\
\hline Capim colchão & Digitaria horizontalis & DIGHO & IAC \\
\hline Capim-amargoso & Digitaria insularis & DIGIN & IAC \\
\hline Capim-colchão & Digitaria sanguinalis & DIGSA & IAC \\
\hline Capim-arroz & Echinocnloa crusgalli & ECHCG & IAC \\
\hline Arroz-preto & Orysa sativa & ORYSA & IAC \\
\hline Capim-arroz & Echinocnloa colonum & ECHCO & IAC \\
\hline Capim-pé-de-galinha & Eleusine indica & ELEIN & IAC \\
\hline Barbicha de alemão & Eragrossus pilosa & ERAP & IAC \\
\hline Arroz-vermelho & Orysa sativa & ORYSA & IAC \\
\hline Capim-colonião & Panicum maximum & PANMA & IAC \\
\hline Capim-custódio & Penniselum setosum & PESSE & IAC \\
\hline Capim-favorito & Rhynchelytrum repens & RHYRE & IAC \\
\hline Capim-camalote & Rottboellia exaltata & ROOEX & IAC \\
\hline Rabo-de-raposa & Setaria geniculata & SETGE & IAC \\
\hline Capim-massanbará & Sorghum halepense & SORHA & IAC \\
\hline
\end{tabular}

*LAMAN - Laboratório de Microbiologia Agrícola e Molecular do Centro de Ciências Agrárias da Universidade Federal de São Carlos; IAC Instituto Agronômico de Campinas.

de onda de 560nm, correspondendo à concentração aproximada de $10^{8}$ UFC. $\mathrm{ml}^{-1}$. A suspensão bacteriana continha uma mistura em igual proporção dos 10 isolados de Xanthomonas sp. A inoculação foi feita por dois métodos: (i) pulverização das 10 plantas de cada espécie com aproximadamente $10 \mathrm{ml}$ de suspensão bacteriana, utilizando-se um pulverizador de jardina- gem com capacidade para $50 \mathrm{ml}$ e (ii) injeção de $1 \mathrm{ml}$ de suspensão bacteriana a $5 \mathrm{~cm}$ acima do meristema apical de crescimento, com auxílio de uma seringa hipodérmica. Para todos os tratamentos, parte das plantas foi mantida sob câmara úmida para verificar o seu efeito no sucesso da inoculação. A câmara úmida foi obtida cobrindo-se as plantas com saco plástico, durante 
Tabela 2: Isolados de Xanthomonas sp. agente causal da falsa estria vermelha da cana-de-açúcar

\begin{tabular}{|c|c|c|c|c|c|}
\hline & & Isolado & Origem & Variedade & Ano \\
\hline 1 & Xanthomonas sp. & LAFIMEG120 & Valparaiso-SP & RB855113 & 1996 \\
\hline 3 & Xanthomonas sp. & LAFIMEG122 & Barra Bonita - SP & RB855113 & 1996 \\
\hline 4 & Xanthomonas sp. & LAFIMEG124 & Valparaiso - SP & RB855113 & 1988 \\
\hline 6 & Xanthomonas sp. & LAFIMEG 58 & Barra Bonita - SP & RB855113 & 2000 \\
\hline 7 & Xanthomonas sp. & LAFIMEG059 & Barra Bonita-SP & RB855113 & 2000 \\
\hline 8 & Xanthomonas sp. & LAFIMEG060 & Ribeirão Bonito-SP & RB855113 & 2000 \\
\hline 9 & Xanthomonas sp. & LAFIMEG062 & Araras-SP & RB855113 & 2000 \\
\hline
\end{tabular}

24 horas. Para cada método de inoculação, pelo menos 10 plantas de cada cultivar foram inoculadas, sendo outras cinco utilizadas como teste injetando-se ou pulverizando-se água. Cada espécie de gramínea estudada foi submetida a três baterias de testes ao longo de três anos.

Avaliação dos sintomas. Após a inoculação, diariamente as plantas eram avaliadas quanto ao aparecimento de sintomas, até cada espécie completar o seu ciclo de crescimento. Quando algum sintoma era observado, as folhas eram coletadas e examinadas em laboratório. Após a descrição dos sintomas, as folhas eram submetidas ao processo de re-isolamento de Xanthomonas sp. O mesmo processo sorológico e rep-PCR foram utilizados para garantir a identidade das bactérias re-isoladas.

\section{RESULTADOS E DISCUSSÃO}

Dentre as 31 diferentes espécies de gramíneas, apenas Sorghum bicolor (sorgo), Zea mays (milho) e Avena sativa L. (aveia) apresentaram sintomas quando inoculados com Xanthomonas sp. agente causal da FEV da cana-de-açúcar. Os sintomas foram observados, 15 dias após a inoculação.

A variedade de cana-de-açúcar RB855113, sabidamente suscetível a Xanthomonas sp., apresentou os sintomas característicos da falsa estria vermelha somente quando inoculada por injeção. Também não houve a necessidade de câmara úmida para a expressão dos sintomas. Estrias vermelhas finas, alongadas e com mesclas amareladas foram observadas no limbo foliar (Figura 1A). Na face adaxial do limbo foliar, foram observados exsudatos de células bacterianas (Figura 1B), indicando ampla multiplicação de Xanthomonas sp. nos tecidos. Estes exsudatos são também comumente observados em condições de infecção natural, nos campos comerciais de cana-de-açúcar, e servindo como principal fonte de inoculo para a ocorrência de novas infecções (2).

O fato de a inoculação por pulverização não ter induzido sintomas, comprova a necessidade de ferimentos para que Xanthomonas sp. causasse a doença FEV em cana-de-açúcar. A
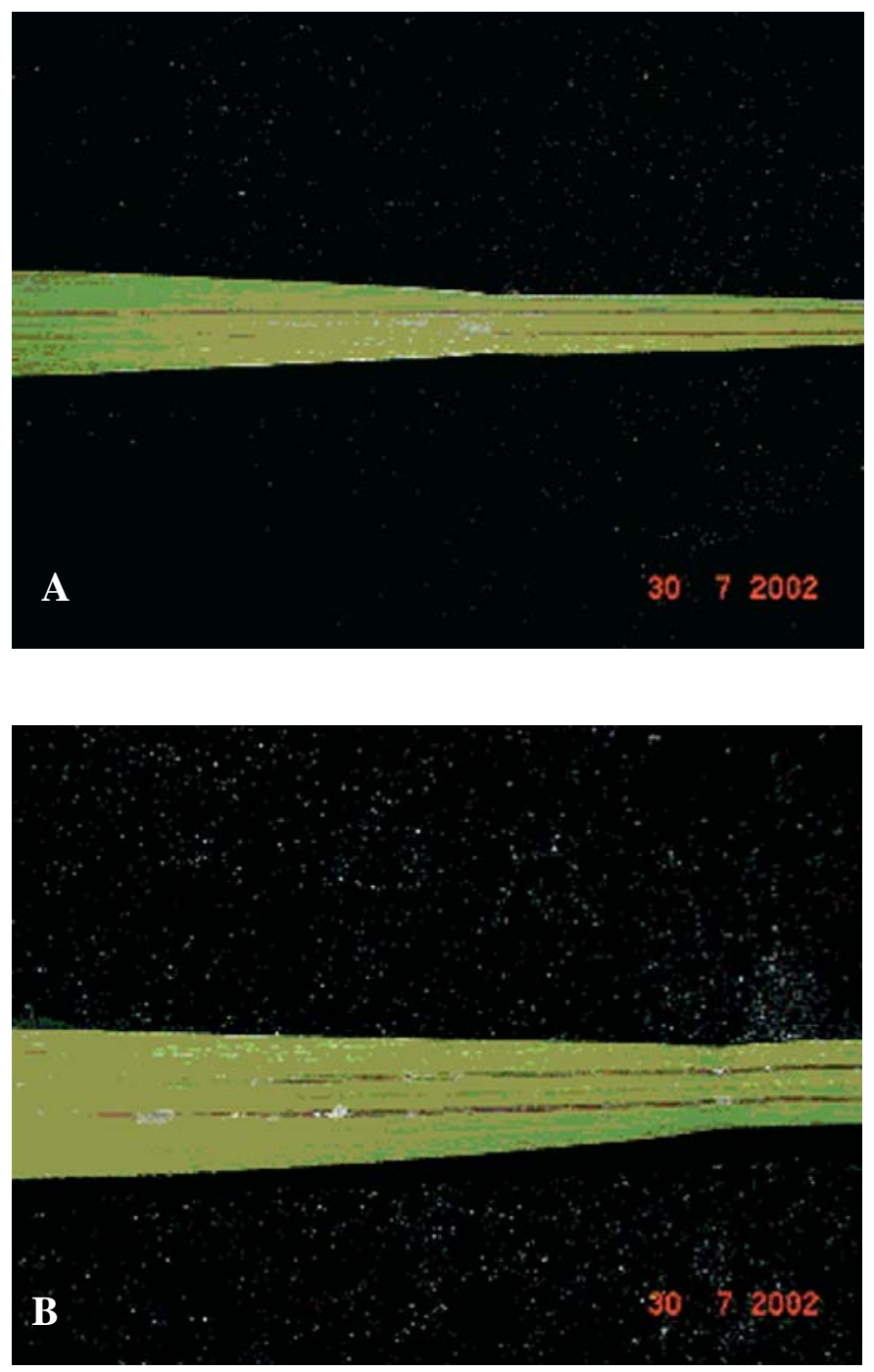

Figura 1. Sintomas induzidos por Xanthomonas sp. em folhas de cana-de-açúcar. 
ocorrência de ferimentos pelo contato foliar já havia sido sugerida como um dos fatores contribuintes para a alta freqüência de infecção em condições de campo (2). A borda do limbo foliar de cana-de-açúcar é serrilhada e rica em sílica. Com o vento, as minúsculas cerdas da borda provocam ferimentos nas folhas das plantas vizinhas. Com o limbo foliar úmido, os exsudatos da bactéria disseminam de uma planta para outra e, com o vento, são levados a longas distâncias.

Em sorgo, os sintomas foram observados nas duas variedades avaliadas, BR700 e BR800. No ponto de inoculação, tanto no limbo (Figura 2A) como na bainha (Figura 2B) foliar, apareceram estrias avermelhadas coalescentes. Folhas que estavam abaixo ou acima do ponto de inoculação por injeção apresentaram típicas estrias vermelhas finas (1mm), longas e paralelas às nervuras (Figura 2C). Até mesmo as inflorescências apresentaram pontuações avermelhadas (Figura 2D). A face adaxial do limbo foliar também apresentou exsudato bacteriano, indicando alta taxa de multiplicação de Xanthomonas sp. Os sintomas induzidos em sorgo foram bastante similares àqueles observados em cana-de-açúcar; porém, sem as típicas mesclas amareladas que são características da FEV.

Plantas de milho das variedades P30, F33 e P30K76 inoculadas com seringa apresentaram sintomas de anasarca e descoloração de tecidos ao redor do ponto de inoculação (Figuras 03A e 03B). No limbo foliar, foram observadas estrias cloróticas (Figura $03 \mathrm{C}$ ); porém, sem exsudato de bactéria na face adaxial (Figura 03D). As longas estrias cloróticas observadas no limbo eram também mais largas ( $3 \mathrm{~mm}$ ) que as observadas em sorgo e cana-de-açúcar.

Apenas folhas da variedade AV107 de aveia apresentaram sintomas quando inoculadas por pulverização. A lesões iniciais eram estrias e manchas de cor palha, evoluindo para uma necrose total das folhas, causando a morte das plantas. Em
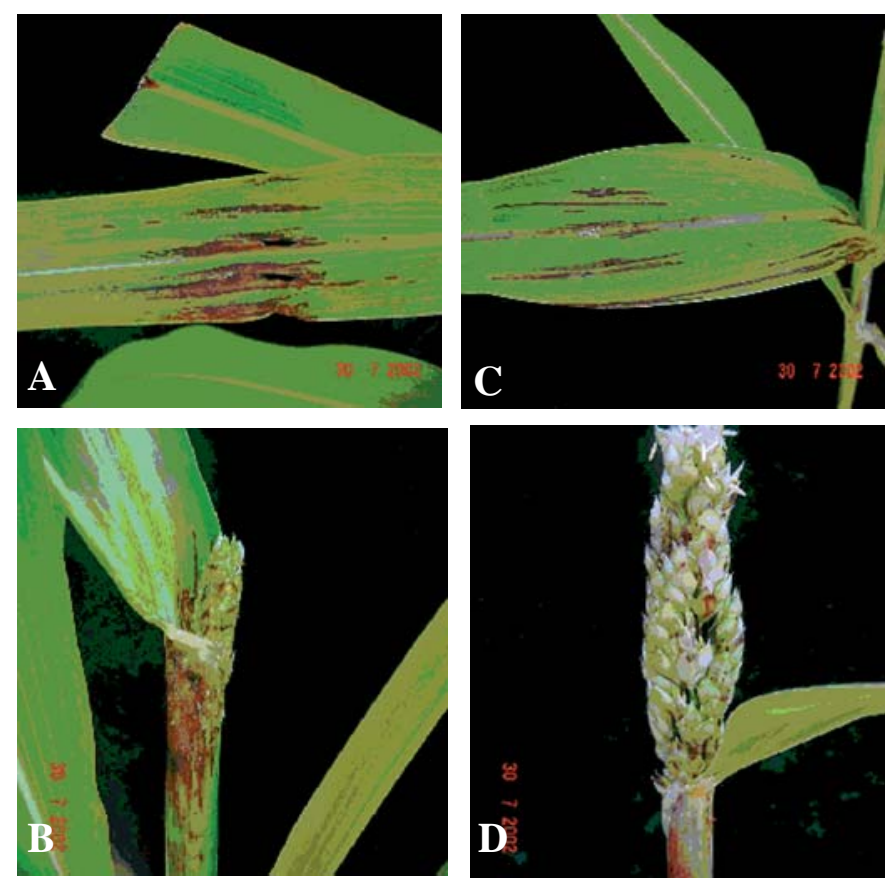

Figura 2. Sintomas induzidos por Xanthomonas sp. em diferentes tecidos de sorgo. arroz, a variedade Epagri também apresentou estrias de cor palha; porém, apenas as pontas de algumas folhas apresentaram sintomas, sem, contudo, evoluir para necrose total e morte das plantas.

A partir de folhas sintomáticas de cana-de-açúcar, sorgo, milho e aveia, realizou-se o re-isolamento, obtendo-se cultura pura de Xanthomonas sp., comprovando ser esta o agente causal dos sintomas observados. A identidade das culturas puras foi comprovada tanto pelos testes sorológicos como por repPCR (dados não apresentados). O mesmo procedimento comprovou a presença da bactéria nos exsudatos observados nas estrias presentes em cana-de-açúcar e em sorgo.

Os resultados obtidos pelo presente estudo indicam que a gama de hospedeiras de Xanthomonas sp. agente causal da falsa estria vermelha é diferente de todas as outras Xanthomonas já isoladas de cana-de-açúcar, indicando uma certa especialização patogênica. Além de Xanthomonas sp., a cana-de-açúcar é hospedeira de pelo menos outras cinco diferentes xanthomonads: X. vasicola pv. holcicola, X. vasicola pv. vasculorum, Xanthomonas sacchari, $X$. axonopodis pv. vasculorum e $X$. albilineans. As duas últimas espécies são os agentes causais da gomose e escaldadura das folhas, respectivamente, que são duas importantes doenças da cana-de-açúcar (13). Apesar da gomose causada por $X$. axonopodis pv. vasculorum ser uma doença tipicamente da cana-de-açúcar (13), espécies de gêneros bastante distantes como as palmeiras Dictyosperma album, Roystonea regia, e Areca catechu, as gramíneas Tripsacum laxum, o bambu (Thysanolaena máxima) e Zea mays são também incluídos como hospedeiros alternativos do agente da gomose da cana-de-açúcar $(11,13)$. Neste particular, X. albilineans, apesar de ser mais facilmente encontrada em seus hospedeiros alternativos, é restrita às gramíneas, incluindo o milho e outras espécies dos gêneros Brachiaria, Imperata, Panicum, Pennisetum e Rottboellia $(8,11,12)$. A bactéria pode sobreviver em Imperata cylindrica por um longo período de tempo e, portanto, esta espécie vegetal pode ser uma constante fonte de inóculo para a cana-de-açúcar. No geral, quando essas
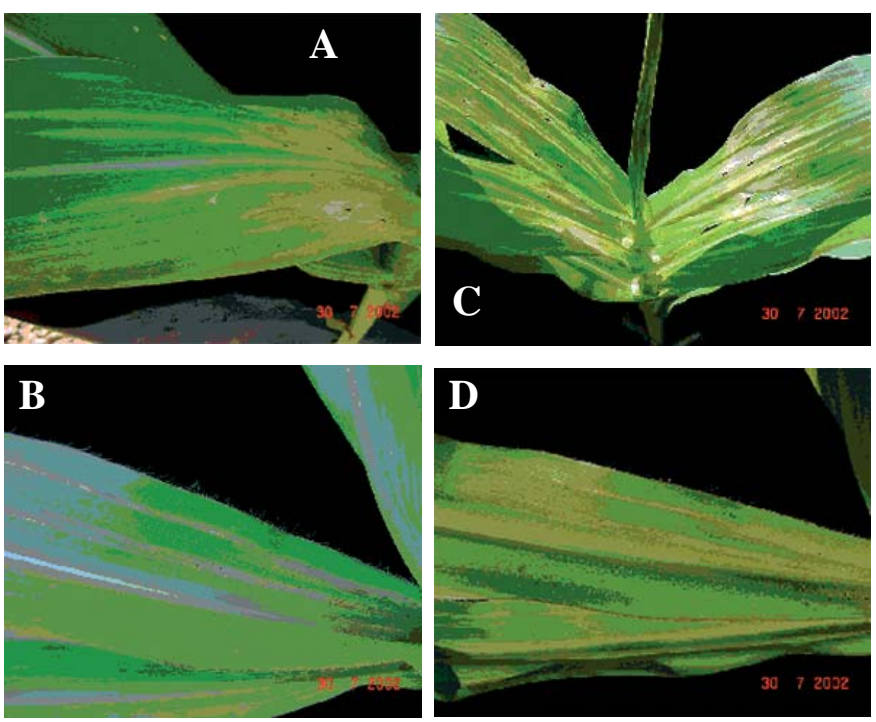

Figura 3. Sintomas induzidos por Xanthomonas sp. em folhas de milho. 
gramíneas estão doentes, elas exibem apenas finas estrias foliares ou o mais característico sintoma da escaldadura das folhas. Com exceção do milho, nenhuma dessas gramíneas expressou sintomas quando inoculadas por Xanthomonas sp. agente causal da falsa estria vermelha.

Xanthomonas vasicola pv. vasculorum incluem isolados de $X$. campestris pv. vasculorum tipo B, os quais também estão envolvidos com a gomose da cana-de-açúcar (16). Portanto, a gama de hospedeiros de $X$. vasicola pv. vasculorum é similar à da $X$. axonopodis pv. vasculorum que causa a gomose tipo A. Isolados de $X$. sacchari obtidos de cana-de-açúcar em Guadalupe foram inicialmente identificados como $X$. albilineans. Nunca foram capazes de induzir sintomas nem mesmo em cana-deaçúcar e, portanto, tem sua patogenicidade desconhecida.

$X$. vasicola pv. holcicola (16) é agente causal da estria foliar bacteriana de Sorghum bicolor ("bacterial leaf streak"), uma das doenças mais prevalentes desta cultura, sendo também isolada de Holcus spp. (10). A partir de cana-de-açúcar, a bactéria foi isolada em 1987, nas Ilhas Reunião, a partir de tecidos foliares com estrias vermelhas (9). Inicialmente, suspeitou-se que a bactéria isolada fosse um isolado particular de X. campestris pv. vasculorum, o agente causal da gomose. No entanto, a bactéria foi identificada como $X$. campestris pv. holcicola, com base em aspectos culturais, reações fisiológicas e patogênicas, perfil de ácidos graxos e padrão de polimorfismo no tamanho de fragmentos de DNA genômico obtidos por cortes com enzimas de restrição - RFLP (9).

Observações de campo têm demonstrado que a bactéria da falsa estria vermelha é facilmente disseminada por respingos de água levados pelo vento ou aerossóis. Num campo experimental destinado ao melhoramento genético da cana-de-açúcar, em Conchal, SP, portanto implantado com seedlings obtidos a partir de sementes, em 2003, plantas com cinco meses de idade apresentaram falsa estria vermelha, apesar de não haver canade-açúcar na área, no ano anterior (dados não publicados). Portanto, canaviais ou outras culturas mesmo distantes podem servir como reservatório de inóculo que, pelo movimento de aerossóis ou poeira, alcançam novas áreas de plantio. Quanto a outras culturas, o sorgo, milho e aveia podem agir como hospedeiros naturais, pois, como demonstrado no presente estudo, estas plantas manifestam sintomas quando inoculadas artificialmente com suspensão bacteriana de Xanthomonas sp., agente causal da FEV. Essa hipótese pode ser ainda mais evidente no caso do sorgo que apresentou os sintomas muito parecidos com aqueles observados em cana-de-açúcar com FEV, incluindo exsudato na fase adaxial das folhas. Para comprovar esta hipótese, inspeções em campos de sorgo são necessárias para verificar se existe infecções naturais e sintomas induzidos por Xanthomonas sp.

\section{AGRADECIMENTOS}

Os autores agradecem a Fundação de Amparo à Pesquisa do Estado de São Paulo (FAPESP) o suporte financeiro para a realização deste trabalho (Processo: 01/12092-0) e pela bolsa de iniciação científica concedida a Elaine S. Mantovani. Agradecem também o Centro Nacional de Pesquisa e Desenvolvimento $(\mathrm{CNPq})$ pela bolsa concedida a Danyelle Marini.

\section{REFERÊNCIAS BIBLIOGRÁFICAS}

1. Clerc, F. Diversité génétique des Xanthomonas pathogènes de la canne à sucre. 1997. 60 f. Dissertação (Mestrado em Bioengenharia). Institut Universitaire Professionnalisé, Université Paul Sabatier - Toulouse III, Montpellier.

2. Giglioti, E.A.; Matsuoka, S. False red stripe. In: Rott, P.; Bailey, R.A.; Comstock, J.C.; Croft, B.J. A guide to sugarcane diseases. Montpellier: Cirad Publications Service, 2000. p.27-31.

3. Giglioti, E.A.; Almeida, I.M.G.; Clerc, F.; Rott, P.; Chatenet, M.; Beriam, L.O.; Carvalho, M.L.V.; Masuda, Y.; Matsuoka, S. False red stripe: a new disease of sugarcane in Brazil. In: Congress of the International Society of Sugar Cane Technologists, 23., 1999, New Delhi, India Proceedings ISSCT, 1999. 382 p.

4. Giglioti, E.A.; Almeida, I.M.G.; Clerc F.; Rott, P.; Chatenet, L.O.; Beriam, L.O.; Carvalho, M.L.V.; Masuda, Y.; Matsuoka, S. False red stripe in Brazil: epidemiology and causal agent. In: Rao, G.P.; Saumtally, S.; Rott, P. Sugarcane pathology: bacterial and nematode diseases. Enfield: Science Publishers, 2004. p. 127134.

5. Marchiori. A.C.; Marini, D.C.; Giglioti, E.A. Dinâmica populacional e diversidade de Xanthomonas sp. em cana-de-açúcar de diferentes regiões geográficas do Brasil, através da técnica rep-PCR. In: Congresso Nacional de Genética, 49., 2003, Águas de Lindóia. Anais, Ribeirão Preto: USP, 2003.

6. Marchiori, A.C.; Marini, D.C.;. Diaz, M.R.; Giglioti, E.A. Specific genomic fingerprint of xanthomonas sp., causal agent of false red stripe disease of sugarcane, generated by rep-pPCR. Summa Phytopathologica, Botucatu, v.29, n. 1, p.99, 2003. (Resumo).

7. Marini, D.C. Estudo polifásico para a determinação da posição taxonômica da Xanthomonas sp. agente causal da falsa estria vermelha da cana-de-açúcar. 2005. 104 f. Dissertação (Mestrado Biologia Celular e Molecular). Instituto de Biociências, Universidade Estadual Paulista, Rio Claro.

8. Martin, J.P.; Robinson, P.E. Leaf scald In: Martin, J.P.; Abbott, E.V.; Hughes, C.G. Sugar Disease of the World. Amsterdam: Elservier Publishing, 1961. v.1, p.79-107.

9. Peros, J.P.; Girard, J.C.; Lombard, H.; Janse, J.D.; Berthier, Y. Variability of Xanthomonas campestris pv. vasculorum from sugarcane and other gramineae in Reunion Island. Characterization of a different xanthomonads. Journal of Phytopathology, Berlin, v.142, n.3-4, p.177-188, 1994.

10. Qhobela, M.; Claflin, L.E. Eastern and Sourthern African strains of Xanthomonas campestris pv. vasculorum are distinguishable by restriction fragment length polymorphism of DNA and polyacrylamide gel electrophoresis of membrane proteins. Plant Pathology, London, v.41, n.2, p.113-121, 1992.

11. Ricaud, C.; Autrey, L.J.C. Gumming Disease. In: Ricaud, C.; Gillaspie Jr., A.G.; Hughes, C.G. Diseases of sugarcane. Major diseases. Amsterdam: Elsevier Science Publishers,1989. p. 2138.

12. Rott, P.; Davis, M.J. Leaf scald. In: Rott, P.; Bailey, R. A.; Comstock, J. C.; Croft, B. J.; Saumtally, A. S. A guide to sugarcane diseases. Montpellier: Cirad Publications Service, 2000. p.3844.

13. Saumtally, S.A.; Dookum, A. Gumming. In: Rott, P.; Bailey, R. A.; Comstock, J. C.; Croft, B. J.; Saumtally, A. S. A guide to sugarcane diseases. Montpellier: Cirad Publications Service, 2000. p.32-37. 
14. Souza, L.; Marini, D.C.;. Diaz, M.R; Giglioti, É. A. Comparison of sugarcane false red stripe bacterium with other Xanthomonas species by rep-PCR. Summa Phytopathologica, Botucatu, v.29, n. 1, p.101, 2003. (Resumo).

15. Souza, L. Caracterização e diagnose molecular de Xanthomonas sp., agente causal da falsa estria vermelha da cana-deaçúcar no Brasil. 2004. 84 f. Dissertação (Mestrado em genética e evolução) Centro de Ciências Biológicas e da Saúde, Universida- de Federal de São Carlos, São Carlos.

16. Vauterin, L.; Hoste, B.; Kersters, K.; Swings, J. Reclassification of Xanthomonas. International Journal of Systematic Bacteriology, Washington, v.45, n.3, p.472-489, 1995.

17. Wilbrink, G. De gomziekte van het suikerret hare oorzaak in hare bestrijding. Archief voor Suikerindustrie, Nederlsndsch-Indie, v. 28, p. 1399-1525, 1920. 